\title{
LARANGAN UNTUK PEMINDAHAN TANAH DALAM MASYARAKAT HUKUM ADAT BALI: PERSPEKTIF HUKUM TANAH NASIONAL
}

\author{
I Made Suwitra ${ }^{1}$
}

\begin{abstract}
Traditional as communal land which is tenanted individually, whether in the form of Pekarangan Desa or Ayahan Desa, has religious and communal aspects because it is always attached to the ayahan as the form of individual duty of the tenant for serving their traditional village. But, lately, most of the land has been converted into full individual land based on Law No 5 year 1960, so that the land does not have communal and religious aspect, but it has social functions in the form of secularism. In some traditional villages in Bali nowadays the transference of the tenancy of the communal land can not be avoided so that it can make conflict because up till now there hasn't been any clear agreement in understanding the tenancy, ownership, including the transference, in which for this time the understanding is only in relation to right of the tenant, not the status of the land.
\end{abstract}

Keywords: transference, communal land, ayahan, conflict

\begin{abstract}
Abstrak
Tradisi sebagai tanah komunal yang disewakan secara individual, baik dalam bentuk Pekarangan Desa atau Ayahan Desa, memiliki aspek religius dan komunal karena selalu melekat pada ayahan sebagai bentuk kewajiban individu dari penyewa untuk melayani adat desa mereka. Tapi, akhir-akhir ini, sebagian besar lahan telah dikonversi menjadi lahan individu penuh berdasarkan UU No 5 tahun 1960, sehingga tanah tidak memiliki aspek komunal dan agama, tetapi memiliki fungsi sosial dalam bentuk sekularisme. Di beberapa adat desa di Bali saat pemindahan dari penyewaan tanah komunal tidak dapat dihindari dapat membuat konflik karena sampai sekarang belum ada perjanjian yang jelas dalam memahami penyewaan, kepemilikan, termasuk pemidahan, yang untuk saat ini pemahaman ini hanya dalam hubungannya dengan hak penyewa, bukan status tanah.
\end{abstract}

Kata kunci: pemindahan, tanah komunal, ayahan, konflik

\footnotetext{
${ }^{1}$ Penulis ada Staf Pengajar pada Fakulta Hukum Universitas Marwadewa, Denpasar. Alamat kontak: madesuwitra@yahoo.co.id.
} 


\section{Pendahuluan}

\section{Latar Belakang}

Penguasaan dan pemilikan atas tanah adat di Bali saat ini dipahami secara beberda oleh prajur adat, warga masyarakat, dan pemerintah sehingga dapat memicu konflik horizontal maupun vertikal. Beberapa contoh konflik yang yang dapat diungkapkan seperti: kasus rebutan sumber air antar warga Desa Kutuh Kintamani Bangli dengan warga desa Tejakula Buleleng. ${ }^{2}$ Kasus rebutan tanah "setra" antar warga Banjar Semana dengan Ambengan Ubud Gianyar," antar warga Adat Besang Kangin dengan warga adat Banjar Bucu Klungkung. ${ }^{4}$ Kasus rebutan tanah "laba pura", seperti yang terjadi antara pemaksan Pura Dalem Agung dengan pemaksan Pura Dalem Geria Keramas Sukawati Gianyar, ${ }^{5}$ antara warga adat pemegang sertifikat dengan krama Desa Adat Lemukih, ${ }^{6}$ Penjualan tanah Pekarangan Desa (PKD) di Desa Adat Kemenuh Sukawati Gianyar, ${ }^{7}$ penyepihan (pengkaplingan) tanah Ayahan Desa (AYDS) di Desa Adat Tamanbali Bangli, ${ }^{8}$ konflik loloan Yeh Poh antara warga desa adat Munggu dengan pihak investor yang nyata-nyata melanggar sepadan pantai dan kawasan limitasi, serta merusak kawasan yang disucikan oleh umat hal. 4 .

${ }^{2}$ Usut Tuntas Kasus Perusakan Bak Penampungan Air di Kutuh, Bali Post, 15 Januari 2010,

${ }^{3}$ Tiga Opsi Selesaikan kasus Semana-Ambengan, Bali Post, 2 Mei 2009, hal. 4.

4 'klian Bajar Bucu Tolak Tanda Tangani Kesepakatan, Bali Post, 10 Oktober 2008. hal. 4.

${ }^{5}$ Kisruh Laba Pura, Tegang "Paruman" Desa Dijaga Aparat Keamanan, Bali Post, 28 Sepetember 2009. hal. 4.

${ }^{6}$ Kasus tanah Adat Lemukih, Giliran Pemegang Sertifikat Datangi KP Buleleng, Bali Post, 16 Januari 2007, hal. 5, dan 15 Agustus 2009, hal. 4.

7 Ratusan Warga Desa Adat Kemenuh Sukawati Gianyar Turun Ke Jalan Untuk Menghadang Proses Eksekusi Tanah Sengketa Yang Oleh Warga Disinyalir Berstatus Tanah Ayahan Desa, Bali Post, 1 Maret 2006. hal 5.

${ }^{8}$ Tokoh Siladan-Sema Bertemu", Bali Post, 24 Februari 2006. hal. 2. 
Hindu. ${ }^{9}$ Masih banyak konflik lain dalam komunitas adat yang belum dapat disebutkan secara rinci yang mengindikasikan, bahwa telah terjadi perubahan dalam komunitas masyarakat adat.

Berlakunya Undang-undang Nomor 5 Tahun 1960 tentang Peraturan Dasar Pokok-Pokok Agraria (UUPA) dinyatakan sebagai tonggak yang sangat penting dalam sejarah perkembangan agraria/pertanahan di Indonesia. ${ }^{10} \mathrm{Salah}$ satu misi yang ingin direfleksikan adalah unifikasi hukum dalam bidang hukum pertanahan. Namun harus diakui, bahwa unifikasi tersebut bersifat unik karena masih memberikan kemungkinan berlakunya hukum adat dan agama dalam bidang pertanahan.

Pengakuan hukum adat dalam UUPA secara jelas dapat dicermati melalui Konsiderans/Berpendapat yang menyatakan, bahwa "perlu adanya hukum agraria nasional, yang berdasarkan atas hukum adat tentang tanah". Dalam Pasal 5 ditemukan adanya pernyataan, bahwa "Hukum agraria yang berlaku atas bumi, air dan ruang angkasa ialah hukum adat". Dengan demikian hukum adat di samping menjadi sumber utama, juga sebagai sumber pelengkap dalam pembentukan Hukum Agraria Nasional. Dengan kata lain, konsepsi/falsafah, asas-asas, dan lembaga hukum serta sistem pengaturan yang menjadi isi politik HTN terutama diperoleh dari hukum adat. ${ }^{11}$

Hubungan fungsional antara UUPA dengan hukum adat ini tampaknya relevan dengan kondisi Negara Indonesia yang bercorak multikultural, multi etnik, agama, ras dan multi golongan. Juga relevan dengan sesanti Bineka Tunggal Ika yang secara de facto mencerminkan kemajemukan budaya bangsa dalam naungan Negara Kesatuan Republik Indonesia. ${ }^{12}$ Jadi warna pluralisme hukum tampaknya masih mendapat tempat, dibina dan dikembangkan.

${ }^{9}$ Investor Diminta Respons Aspirasi Warga, Bali Post, 19 April 2006, hal. 2.

${ }^{10}$ Boedi Harsono, "Hukum Agraria Indonesia Sejarah Pembentukan UUPA Isi dan Pelaksanaannya. Jilid I Hukum Tanah Nasional", Cetakan Kesembilan (Edisi revisi), (Jakarta: Djambatan, 2003), hal. 1.

${ }^{11}$ Oloan Sitorus dan H.M. Zaki Sierrad, "Hukum Agraria di Indonesia Konsep Dasar dan Implementasi”, Cetakan Perdana, (Yogyakarta: Mitra Kebijakan Tanah Indonesia, 2006), hal. 47.

${ }^{12}$ I Nyoman Nurjaya, "Pengelolaan Sumber Daya Alam dalam Perspektif Antropologi Hukum", Cetakan I. Kerjasama Progran Magister Ilmu Hukum Program Pascasarjana Unibraw, ARENA HUKUM Majalah Fakultas Hukum Universitas Brawijaya dengan Penerbit Universitas Negeri Malang (Malang: UM PRESS, 2006), hal. 1. 
Berlakunya UUPA dalam kenyataannya justru menjadi referensi terjadinya peralihan tanah-tanah adat untuk menjadi tanah individu penuh yang sekularistik dengan alasan demi kepastian hukum. Di samping itu saat ini sering terjadi konflik setelah terjadi peralihan hak atas tanah adat secara ipso facto dengan alasan dilarang melakukan pengasingan tanah adat kepada orang yang bukan sebagai warga persekutuan hukum adat (desa adat).

\section{Permasalahan}

Mencermati latar belakang tersebut dalam diuraikan di atas, akan dikaji makna pengasingan tanah adat dalam perspektif Hukum Agrria Nasional.

\section{Metode Penelitian}

Kajian dalam masalah ini menggunakan penelitian hukum normatif atau penelitian hukum doktrinal artinya yang hanya menggunakan data sekunder saja yang selanjutnya disebut bahan hukum. ${ }^{13}$ Sedangkan pendekatan yang digunakan adalah pendekatan perundang-undangan (statute approach) dengan pertimbangan masih ada kekosongan norma, dan kekaburan norma dalam UUPA terutama terhadap regulasi, konversi hak-hak atas tanah-tanah adat sebagai tanah komunal.

Pendekatan lain yang dianggap cukup relevan adalah pendekatan analitis (analytical approach) yaitu dalam arti untuk mengetahui makna yang dikandung oleh istilah-istilah yang digunakan dalam aturan perundangundangan secara tekstual, sekaligus mengetahui kontekstualnya terutama dalam penerapannya melalui praktek dan putusan-putusan hukum, dan yang dilengkapi dengan pendekatan kasus, ${ }^{14}$ terutama dalam menganalisis konsep larangan pengasingan tanah dalam perspektif UUPA.

Bahan hukum dalam penelitian ini dikumpulkan dengan studi dokumentasi, dan pencatatan dengan sistem file, selanjutnya dianalisis dengan model hermeneutics analisys, artinya mencoba mencari makna dan

\footnotetext{
${ }^{13}$ Ronny Hanitijo Soemitro, "Metodologi Penelitian Hukum", Cetakan Pertama, (Jakarta: Ghalia Indonesia, 1983), hal. 9.

${ }^{14}$ Johnny Ibrahim, "Teori \& Metodologi Penelitian Hukum Normatif", Edisi Revisi. Cetakan Kedua, (Malang: Bayumedia Publishing, 2006), hal. 98.
} 
merumuskannya dengan cara memberikan interpretasi teks yang menjadi objek untuk ditafsirkan dalam konteks ruang dan waktu. ${ }^{15}$

\section{Larangan Pengasingan Tanah}

Larangan pengasingan tanah dalam peraturan perundangan awalnya diregulasi dalam Stb. 1875-179 yang mengatur mengenai Grondvervreemdings verbood (larangan pengasingan tanah). Dalam larangan pengasingan tanah ini fihak golongan rakyat Indonesia (yang kini dikenal dengan Indonesia asli) dinyatakan tidak mungkin mengasingkan tanah miliknya (tanah dengan hak-hak adat). ${ }^{16}$

Falsafah yang mendasari hukum adat mengenai tanah adalah konseptual komunalistik religius, artinya hubungan antara manusia pribadi dengan masyarakat selalu mengatasnamakan atau mendahulukan kepentingan masyarakat ${ }^{17}$. Oleh karena itu hukum adat memandang kehidupan individu sebagai kehidupan yang terutama diperuntukkan buat mengabdi kepada masyarakat. ${ }^{18}$

Tanah adat sebagai hak kepunyaan bersama dari suatu masyarakat hukum adat dipandang sebagai tanah bersama yang merupakan "pemberian/anugerah" dari suatu kekuatan gaib, sehingga semua hak perorangan bersumber dari tanah bersama tersebut. Adalah relevan dengan pernyataan IB. Lasem dalam hubungan dengan penguasaan ini, bahwa tanah-tanah adat seperti Pekarangan Desa (PKD), Ayahan Desa (AYDS) yang dikuasai secara individu di dalamnya terkandung konsep Tri Hita Karana, yaitu berupa Parhyangan yang berwujud Merajan (believe system), Pelemahan yang berwujud wilayah perumahan (artefact system), dan Pawongan yang berwujud anggota keluarga yang tinggal di situ (social system) yang notabene sebagai krama banjar dan krama desa adat. Semuanya ini sudah barang tentu diatur

${ }^{15}$ Earl Babbie, 1999. "The Basics of Social Research", (America: Wadsworth Publishing Company), hal. 260, dan Jazim Hamidi, "Hermeneutika Hukum, Teori Penemuan Hukum Baru dengan Interpretasi Teks”, Cetakan Pertama, (Yogyakarta: UII Press, 2005), hal. 45. hal. 8.

${ }^{16}$ Gouw Giok Siong, "Tafsiran Undang-undang Pokok Agraia”, (Jakarta: PT. Kinta, 1963),

17 Oloan Sitorus, "Kapita Selekta Perbandingan Hukum Tanah", Cetakan Perdana. (Yogyakarta: Mitra Kebijakan Tanah Indonesia, 2004), hal. 21.

${ }^{18}$ R. Supomo, "Hubungan Individu dan Masyarakat dalam Hukum Adat", Cetakan ke-4, (Jakarta: Pradnya Paramita, 1983), hal. 10. 
dalam awig-awig. ${ }^{19}$ Jadi penguasaan tanah adat ini secara ekonomis tidak hanya dimanfaatkan untuk meningkatkan kesejahteraan secara pribadi pemegangnya, tapi juga diabdikan untuk kepentingan bersama dalam bentuk pelaksanaan kewajiban berupa "ayahan" yang mempunyai dimensi sosial dan religius (Desa adat dengan Parhyangan, seperti pura Kahyangan Tiga).

Dalam Pasal 26 Awig-Awig Desa Adat Gianyar disebutkan, bahwa Karang desa ialah "pelemahan Desa pekeraman" yang diserahkan penggunaannya kepada kerama desa (warga desa) turun-temurun dengan kewajiban "nagge ayahan Desa" (memberi tenaga dan materi untuk desa).

Hak pemilikan secara individual dapat timbul apabila syarat de facto berupa bertempat tinggal dalam masyarakat hukum, mengerjakan tanah secara terus menerus, dan syarat de jure berupa pengakuan masyarakat akan pemilikan tersebut, berlaku secara bersamaan dalam diri pribadi yang bersangkutan. ${ }^{20}$

Tanah-tanah adat sebagai tanah ulayat di Bali merupakan tanah bersama yang dikuasai dan dimiliki oleh desa adat secara komunal. Sebagian tanah komunal ini penguasaannya diserahkan (di-derivatif) kepada krama (warga) secara individual yang disebut sebagai hak milik tidak penuh seperti PKD, AYDS. Menurut Grotius, bahwa milik pribadi dikonsepsikan mempunyai hak untuk memiliki dan menggunakan secara pribadi. Jadi ada milik bersama tetapi dapat digunakan untuk kepentingan pribadi. ${ }^{21}$

Beberapa sifat yang menonjol tentang pemilikan secara individu menurut hukum adat antara lain:

1. Pemilikan tanah hanya dapat dipunyai oleh warga masyarakat hukum saja.

2. Pemilikan tidak lahir berdasarkan keputusan atau izin kepala adat. Keputusan atau izin kepala adat hanya berfungsi sebagai pembuka jalan ke arah kemungkinan menguasai tanah dengan hak milik. Pemilikan lahir berdasarkan pengakuan masyarakat yang disebabkan oleh kenyataan erat

${ }^{19}$ I Made Suwitra, "Eksistensi Hak Penguasaan dan Pemilikan Atas Tanah Adat di Bali dalam Perspektif Hukum Agraria Nasional", Cetakan Pertama, (Bandung: Logoz Publishing, 2010), hal. 73 .

${ }^{20}$ Herman Soesang Obeng, Pertumbuhan Hak Milik Individuil Menurut Hukum Adat dan Menurut UUPA di Jawa Timur, Majalah Hukum, II-1975, (3), hal. 51. 2001), hal. 59.

${ }^{21}$ A. Sonny Keraf, "Hukum Kodrat \& Teori Hak Milik Pribadi”, (Yogyakarta: Kanisius, 
tidaknya hubungan seseorang atas tanah. Erat dalam arti tanah senantiasa dikerjakan, dirawat dengan baik dan tidak diabaikan.

3. Pemilikan hanya timbul apabila syarat de facto berupa bertempat tinggal dalam masyarakat hukum, mengerjakan tanah secara terus menerus, dan syarat de jure berupa pengakuan masyarakat akan pemilikan tersebut, berlaku secara bersamaan dalam diri pribadi yang bersangkutan.

4. Berakhirnya hak milik atas tanah, berarti berhentinya pengakuan masyarakat atas hak orang yang bersangkutan. ${ }^{22}$

Konsep "beschikkingrecht" dari van Vollenhoven sangat membantu dalam memahami hubungan penguasaan tanah dalam desa tradisional yang dapat dikenali dari dua unsur utama yakni, pertama: tiadanya kekuasaan untuk memindahkan tanah, dan kedua, terdapat interaksi antara hak komunal dan hak individu yang mempunyai akibat atau berlaku ke dalam maupun berlaku ke luar. ${ }^{23}$ Ini berarti, bahwa tanah ulayat pada prinsipnya hanya diperuntukkan bagi warga persekutuan, tetapi masih dimungkinkan bagi orang luar untuk memanfaatkan asal ada izin kepala persekutuan.

Dengan berlakunya UU No.62 Tahun 1958 tentang kewarganegaraan, penduduk di Indonesia hanya dibedakan antara WNI dan WNA, sehingga larangan pengasingan hak atas tanah hanya ditujukan kepada WNA (Pasal 16 Jo 21 UUPA).

Di Bali "larangan pengasingan" ini di beberapa desa adat sering dijadikan alat referensi untuk menggagalkan adanya peralihan hak atas penguasaan dan pemilikan tanah (adat) sehingga timbul konflik yang berlarut-larut walaupun sudah diputusakan melalui lembaga pengadilan.

Hubungan penguasaan tanah adat antara hak komunal dengan hak individual di Bali nampak saling mendesak, menebal dan menipis, mulur-mungkret. Bahkan saat ini lebih didominasi oleh hak individual, terutama dalam pemanfaatan tanah pekarangan beserta telajakannya. ${ }^{24}$ Proses menebal dan menipisnya hubungan hak komunal dengan hak individu itu nampaknya sangat bergantung pada kepekaan prajuru adatnya dan kesadaran krama desa terhadap tanah-tanah adat yang dikuasainya dalam menentukan apakah hak milik komunal akan berubah statusnya

${ }^{22}$ Herman Soesang Obeng, Op. Cit., hal. 52.

${ }^{23}$ R. Van Dijk, "Pengantar Hukum Adat Indonesia", Terjemahan A. Soehardi, Cetakan Ketujuh, (Jakarta: Sumur Bandung, 1971), hal. 43.

${ }^{24}$ I Made Suwitra, Tugas Prajuru Adat Dalam Mengatur Tanah Adat Khususnya Tanah Telajakan Dalam Konsep Menuju Bali Yang Ajeg, Kertha Wicaksana, Fakultas Hukum Universitas Warmadewa, Denpasar, 11-2005, (1), hal. 15. 
menjadi hak milik individu penuh. Tanah yang dulunya termasuk tanah adat ada kalanya sudah dialihkan menjadi hak milik individu penuh yang lebih dikenal dengan tanah Sertifikat Hak Milik (SHM), seperti tanah AYDS yang ada di Desa Adat Kemenuh Gianyar sebagai akibat dikeluarkannya surat pajak oleh pemerintah, padahal awalnya AYDS merupakan satu kesatuan dengan tanah PKD.

Desa adat dalam hal ini tampaknya belum memahami implikasi adanya konversi dari AYDS menjadi tanah individu penuh, dan saat ini baru sadar, karena AYDS pada dasarnya merupakan satu kesatuan fungsi (nutug) dengan PKD, sehingga keperluan hidup dan kewajiban ayahan ke desa adat dijamin dari AYDS tersebut.

Tanah-tanah adat ini disebutkan sebagai "druwe" atau "druwen" desa (adat), berarti gelah (Bali) atau kepunyaan, milik, kekuasaan desa adat. ${ }^{25}$ Jadi tanah-tanah yang ada dalam wilayah (wewengkon) desa adat merupakan druwe (n) desa, kecuali tanah pribadi penuh. Jadi dari konsep druwe ini, tanah-tanah adat sebagai tanah ulayat ada dalam kekuasaan desa adat, konsekuensinya muncul wewenang untuk mengurus dalam arti memelihara dan memimpin peruntukannya (dimensi publik), juga yang secara langsung memanfaatkan untuk kepentingan umum (dimensi privat), seperti untuk setra, pasar desa, balai desa.

Penguatan hubungan antara desa adat dengan tanahnya itu, kemudian dibuatkan aturan yang kemudian disuratkan dalam awig-awig yang melarang adanya pengalihan hak atau jual beli tanah kepada orang yang bukan sebagai krama desa setempat, juga dilarang untuk mengagunkan tanah dimaksud, kecuali dipergunakan sesuai dengan tujuan (petitis) dalam awig-awig dan memperoleh persetujuan melalui paruman desa. Larangan ini dapat dicermati dalam awig-awig desa adat, seperti Desa Adat Ngis Karangasem, Desa Adat Siladan Bangli, Desa Adat Gianyar, Desa Adat Tusan Klungkung.

Hubungan yang erat antara desa adat dengan tanah adatnya yang bersifat religio magis ini nampak sekali dari adanya Kahyangan Tiga sebagai unsur esensial di setiap desa adat. Adanya tempat suci yang disebut sanggah atau merajan pada setiap pekarangan rumah krama desa. Di setiap setra juga ada tempat sucinya yang disebut Pura Prajapati. Sedangkan di setiap pasar ada Pura Melanting.

Secara umum hak penguasaan atas tanah atau yang juga disebut hak atas tanah adalah hubungan hukum yang memberi wewenang untuk berbuat sesuatu atas tanah itu. Hak penguasaan atas tanah ini dapat dipakai dalam arti fisik dan yuridis.

${ }^{25}$ IW. Simpen, "Kamus Bahasa Bali", (Denpasar: PT. Mabhakti, 1985), hal. 60. 
Pengertian penguasaan dan menguasai di sini dapat berdimensi perdata dan publik, namun pemilahan secara tegas tidak dikenal dalam hukum adat. Penguasaan dalam dimensi perdata adalah penguasaan yang memberi "wewenang untuk mempergunakan" tanah yang bersangkutan, sedangkan penguasaan dalam dimensi publik, memberi "wewenang kepada pemegangnya (desa adat) untuk mengurus dan mengatur" tanah (wilayah) yang dikuasainya. ${ }^{26}$

Hak penguasaan atas tanah oleh desa adat di Bali dapat dikelompokkan menjadi dua kelompok utama, yaitu: Hak milik individu dan hak milik komunal. Secara rinci menurut pengamatan penulis, dapat digambarkan dalam bagan sebagai berikut:

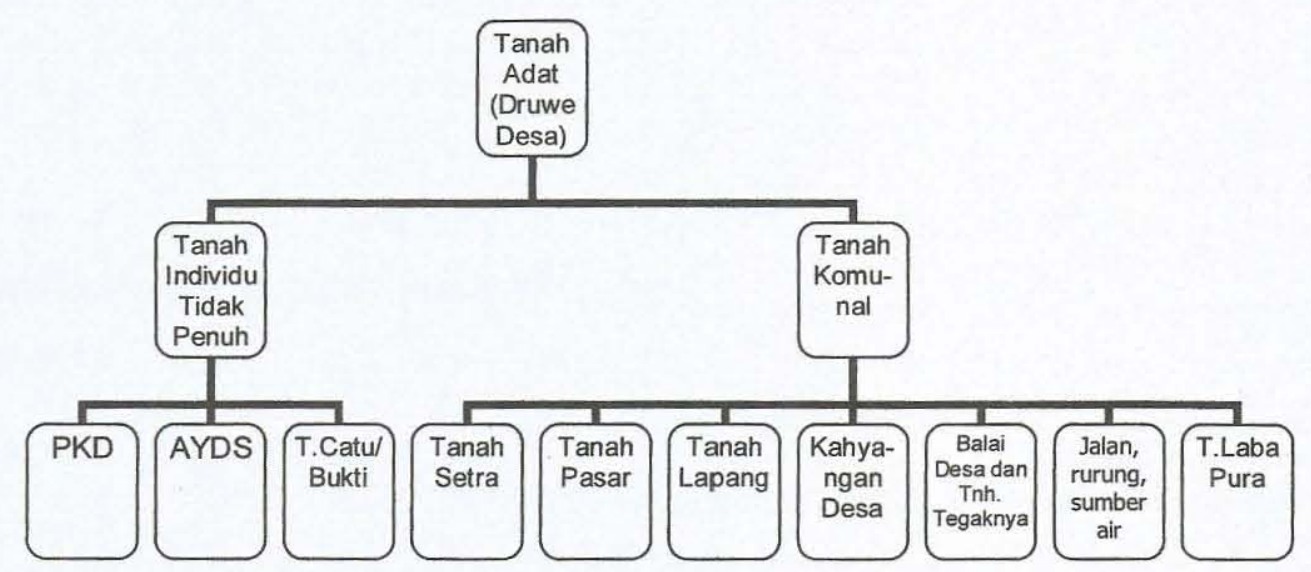

Dari bagan di atas, dapat dicermati bahwa konsep komunal religius dalam penguasaan dan pemilikan tanah adat ada dalam ikatan kemasyarakatan dalam bentuk "ayahan" yang mempunyai dimensi sosial dan religius, artinya pemegang tanah adat diikat oleh kewajiban untuk mengabdi kepada banjar dan desa adatnya di satu sisi, sedangkan di sisi lain wajib berbakti kepada Tuhan Yang Maha Esa melalui ayahan ke pura.

Dalam perspektif UUPA, tampaknya masalah larangan pengasingan tanah masih tetap ada, namun dalam konteks antara warga negara Indonesia (WNI) kepada

${ }^{26} \mathrm{~K}$. Oka Setiawan, "Hak Ulayat Desa Adat Tenganan Pegringsingan Bali Pasca UUPA", Cetakan I. Disertasi. (Jakarta: Program Pascasarjana Fakultas Hukum Universitas Indonesia, 2003), hal. 105 . 
warga negara asing (WNA) seperti yang ditegaskan dalam Pasal 21 UUPA. Di mana hanya WNI saja yang dapat diizinkan untuk mempunyai hak milik atas tanah.

\section{Kasus Pengasingan Tanah Adat}

\section{Latar Belakang Timbulnya Konflik}

I Wayan Kn krama Banjar Kemenuh, Desa Adat Kemenuh Kecamatan Sukawati Kabupaten Gianyar menguasai dua bidang tanah PKD secara turun temurun, yaitu: Pertama, tanah seluas lebih kurang $417 \mathrm{~m} 2$ (tanah sengketa I). Kedua, tanah PKD seluas $312,7 \mathrm{~m} 2$ (tanah sengketa II).

Tanah sengketa ini kemudian dikuasai oleh I Made Dn melalui proses pewarisan, sebagai konsekuensi diangkat anak oleh I Wayan $\mathrm{Kn}$ sehingga ayahannya diserahkan kepada I Wayan $\mathrm{Kn}$ (selaku penyilidihi). ${ }^{27}$ Tanah sengketa I kemudian dijual oleh I Wayan Kn dan I Made Dn kepada I Wayan Cdr pada tanggal 28 Maret 1991. Pada tahap ke dua, tanah sengketa II beserta bangunan dengan segala isinya juga dijual kepada I Wayan Cdr pada tanggal 20 September 1992. Proses jual beli ini diketahui oleh aparat desa (baik dinas maupun adat). Pihak pembeli juga menyatakan kesanggupannya untuk melaksanakan "ayahan" jika tanah yang dibelinya itu masih terikat pada "ayahan", namun tidak ditanggapi oleh prajuru adat saat itu. ${ }^{28}$

Walaupun telah dijual, namun tanah beserta bangunannya dikuasai oleh adik I Made Dn, yaitu I Putu Blk atas mandat desa melalui prajuru. Oleh karena itu melalui pihak penjual, telah dimohon secara baik-baik agar tanah dan bangunan beserta segala isinya dapat diserahkan kepada pembeli. Pendekatan melalui aparat desa (dinas dan adat) juga sudah dilakukan, namun tidak ada hasilnya, sehingga untuk penyelesaiannya ditempuh melalui jalur litigasi.

${ }^{27}$ Penyilidihi berasal dari kata silidihi artinya pengganti, wakil. Jadi sentana demikian dimaksudkan sebagai pengganti dalam melakukan ayahan (kewajiban) kepada desa adat, dalam Gde Panetje, "Aneka Catatan tentang Hukum Adat Bali", Cetakan kedua, Denpasar: Guna Agung, 1989), hal. 46.

${ }^{28}$ I Made Suwitra. 2010. Op. Cit., hal. 170. 


\section{Upaya Penyelesaian}

Konflik diupayakan diselesaikan secara damai dan kekeluargaan, juga melalui aparat desa baik desa dinas maupun desa adat, namun tidak dapat diselesaikan, sehingga ditempuh jalur litigasi. Adapun yang dijadikan dasar gugatan adalah sebagai berikut:

1) Penggugat secara riil telah membeli dua bidang tanah dalam dua tahap. Jual beli mana dilakukan di bawah tangan yang diketahui oleh Perbekel atau Kepala Desa, Kepala Dusun, dan Bendesa Adat, di mana tergugat telah membuat kesepakatan untuk menyerahkan tanah, bangunan beserta isinya kepada penggugat; Namun sampai gugatan diajukan tidak mau diserahkan secara sukarela oleh para tergugat, sehingga dapat disangka, bahwa tergugat mempunyai itikad tidak baik;

2) Karena merupakan tanah $\mathrm{PKD}$, penggugat telah melaporkan kehendaknya kepada Bendesa Adat untuk dapat melakukan kewajiban (ayahan) ke banjar menggantikan ayahan yang dulunya dilaksanakan oleh tergugat;

3) Musyawarah untuk mufakat sudah tidak mungkin dilakukan, sehingga untuk memperoleh keadilan dan kepastian hukum ditempuh upaya memohon keputusan hukum melalui lembaga peradilan.

\section{Hasil Penyelesaian}

Dalam Putusan Pengadilan Negeri Gianyar No. 7/Pdt.G/1996/PN/.Gir. yang telah mempunyai kekuatan hukum tetap, dinyatakan, bahwa:

1) Perjanjian jual beli yang dibuat adalah sah;

2) I Wayan Cdr sebagai pembeli, karena mempunyai itikad baik dilindungi oleh Undang-undang;

3) Ke dua bidang tanah sengketa beserta bangunan dengan segala isinya adalah sah milik penggugat ( I Wayan Cdr);

4) Menghukum para tergugat untuk menyerahkan tanah sengketa I dan II berikut bangunan beserta rumah dengan segala isinya kepada penggugat dalam keadaan lasiakosong, bilamana perlu dengan bantuan alat negara/ polisi.

Dalam putusannya, hakim pengadilan negeri mengemukakan beberapa dasar yang dijadikan pertimbangan hukum, yaitu: 
1) Jual beli dua bidang tanah PKD yang telah dilakukan adalah sah walaupun berupa akta di bawah tangan, yaitu yang di dasarkan pada surat pernyataan jual beli, dan kuitansi pembayarannya;

2) Adanya surat kuasa penuh yang dibuat tergugat dihadapkan Kepala Desa yang memberi kuasa kepada penggugat (pembeli) untuk menguasai/menempati tanah sengketa I, dan II. Juga melanjutkan/ meneruskan semua kewajiban (ayahan) secara adat dan kedinasan, sehingga pembeli terbukti mempunyai itikad baik yang wajib dilindungi Undang-undang; dan sebaliknya penjual (tergugat) terbukti telah melakukan perbuatan melawan hukum, yaitu dengan tatap menguasai tanah sengketa yang bukan lagi menjadi haknya;

Dengan keluarnya putusan pengadilan negeri ini, pihak penggugat harus berhadapan lagi dengan Ida Bagus Made Gr selaku Bendesa Adat Kemenuh di pengadilan negeri yang sama, yang kemudian disebut pihak pelawan.

Pelawan selaku bendesa adat tampaknya tidak dapat menerima putusan pengadilan negeri dan tidak mau menerima eksekusi yang telah dimohon melalui pengadilan negeri, sehingga beliau kemudian mengajukan perlawanan kepada I Wayan Cdr (terlawan I), I Made Dn (terlawan II), I Wayan Kn (terlawan III), dan I Putu Blk (terlawan IV). Dasar dari perlawanan yang diajukan antara lain:

1) Sebagai bendesa adat merasa bertanggung jawab untuk melindungi kepentingan krama desanya, baik ke dalam maupun ke luar;

2) Dalam kesepakatan krama desa yang kemudian dituangkan dalam keputusan bendesa adat No. 10/DSA/Tahun 1993 tentang Penetapan Tanah PKD ditentukan, bahwa ke dua tanah sengketa diteruskan kepada terlawan IV ( I Putu Balik) dengan maksud agar ayahannya dapat tetap dilanjutkan;

3) Dalam awig-awig ditentukan, bahwa tanah ayahan desa tidak boleh untuk dijual atau dipindahtangankan tanpa mendapat persetujuan dari paruman desa.

4) Dari ketentuan awig-awig tersebut, maka pihak terlawan II, dan III tidak berhak untuk menjual tanah sengketa kepada pihak terlawan I tanpa sepengetahuan dan tanpa seizin dari desa adat, dengan konsekuensinya jual beli yang telah dilakukan dianggap batal demi hukum karena bertentangan dengan isi awig-awig; 
5) Karena terlawan II, III dan IV dianggap melalaikan kewajibannya dan tidak mampu mengemban kepercayaan yang diberikan oleh desa adat, maka tanah sengketa akan kembali dikuasai oleh desa adat.

6) Pelawan merasa mempunyai itikad baik untuk mengembalikan penguasaan tanah PKD kepada desa adat, karena ada itikad tidak baik dari pihak terlawan I, II, III yang telah melakukan proses jual beli dan pengalihan tanah adat. Juga karena terlawan II, III, dan IV telah lalai melakukan kewajibannya, yaitu tidak menghadiri sidang pengadilan untuk mengawal tanah PKD yang dikuasainya dan digugat terlawan I.

Melalui Putusan No.51/Pdt.Plw/1996/PN.Gir. tertanggal 26 Mei 1997 gugatan perlawanan pelawan ditolak seluruhnya, dan disebut pelawan yang beritikad tidak baik dengan dasar pertimbangan:

1) Tanah sengketa merupakan tanah PKD yang dikuasai perorangan secara turun-temurun;

2) Beberapa saksi yang diminta keterangannya menjelaskan, bahwa secara riil sudah banyak ada pengalihan atau jual beli tanah PKD dengan akta di bawah tangan;

3) Para mantan prajuru menjelaskan, bahwa terlawan II merupakan ahli waris terdekat dengan terlawan III;

4) Dengan adanya tanda tangan prajuru adat (bendesa adat) dalam akta jual beli di bawah tangan berarti krama desa melalui prajurunya sudah dianggap mengetahui dan menyetujui proses jual beli dan peralihan tanah sengketa dimaksud;

5) Keputusan bendesa adat No. 10/DSA/Tahun 1993 tertanggal 22 Desember 1993 tentang penunjukan terlawan IV ( I Putu Balik) sebagai yang berhak menempati tanah sengketa oleh pelawan harus dipandang tidak mengikat menurut hukum, karena peralihan hak atas tanah sengketa sudah beralih sebelumnya, yaitu sejak 28 Maret 1991 dari terlawan II, dan III kepada terlawan I sesuai pernyataan jual beli;

Pelawan belum puas dengan putusan pengadilan negeri ini, kemudian melakukan upaya hukum banding dan kasasi. Di mana melalui Putusan No. 124/PDT/1997/PT.DPS tertanggal 24 September 1997 Pengadilan Tinggi Denpasar telah menguatkan putusan Pengadilan Negeri Gianyar dimaksud. Sedangkan melalui putusan kasasi No. 1918 K/Pdt/1998 tertanggal 14 Maret 2000 Mahkamah Agung juga menolak permohonan kasasi pelawan (Ida Bagus Made Gr), karena tidak ternyata putusan Yudex Facti dalam perkara yang dimohonkan kasasi ini bertentangan dengan hukum dan/atau Undang-undang. 


\section{Analisis}

Dari kasus di atas dapat dianalisis, bahwa larangan pengasingan tanah adat tidak semata-mata harus dinterpretasikan sebagai pengasingan terhadap subjek pemegangnya, tapi lebih pada objeknya, yaitu "status tanahnya". Artinya peralihan antar subjek dapat saja dilakukan sepanjang status "ayahan" dari tanah adat dimaksud selalu melekati pemegangnya dan sanggup dilakukan oleh pemegangnya. Kosekuenasinya pemegang tanah adat sudah siap menjadi krama (warga) banjar atau desa adat yang dilekati kewajiban sosial dan religius sesuai dengan awig-awig.

Di samping itu, pengasingan itu wajib dalakukan secara "terang" artinya dilakukan dengan sepengetahuan kepala adat (prajuru adat) dalam mekanisme paruman (rapat desa). Oleh karena itu, penguasaan dan pemilikan tanah adat dalam perspektif Hukum Agraria Nasional tidak lagi hanya bersumber pada hak ulayat, tapi juga bersumber pada Hak bangsa. Artinya tidak dibenarkan adanya klaim bahwa tanah dalam suatu kepulauan tertentu semata-mata menjadi milik penduduk setempat. Ini berarti perbuatan pengasingan tanah baru ada jika pengalihan hak atas tanah kepada subjek tertentu menyebabkan hilangnya status "ayahan" yang melekati tanah adat dimaksud. Dengan kata lain sepanjang status "ayahan" dari tanah adat yang bersifat komunal religius tidak hilang, maka tanah adat dapat saja dialihkan kepada siapa saja (WNI) menurut mekanisme yang diatur dalam awig-awig desa adat sebagai persekutuan hukum adat. Hasil penyelesian konflik melalui putusan pengadilan telah mencerminkan bahwa larangan "pengasingan" tidak lagi dimaknai berkenaan dengan subjeknya tapi lebih pada objeknya, yaitu status "ayahan" yang melekati tanah adat dimaksud.

Dalam ketentuan awig-awig pun kalau mau dimaknai tidak secara tekstual tapi juga secara kontektual, maka dalam kasus di atas sebenarnya tidak terjadi "pengasingan" terhadap status "ayahan" dari tanah adat yang dialihkan penguasaannya kepada subjek lain, sehingga penolakan dari prajuru adat dan juga masyarakat adat Kemenuh tidak mempuyai alas pijak, baik dari aspek filosofis, yuridis, dan sosiologis.

\section{Simpulan Dan Saran}

Larangan pengasingan tanah adat awalnya memang berlaku dalam konteks antara warga persekutuan hukum adat dengan konsep bahwa hak ulayat berlaku ke 
luar dan ke dalam. Namun saat itu juga dikenal adanya eksepsi, orang luar (asing) dapat memanfaatkan dan menggunakan tanah ulayat asal ada izin dari kepala persekutuan dan telah membayar recognitie. Dengan berlakunya UUPA tampaknya larangan pengasingan hak milik atas tanah tetap dipertahankan dalam konteks Hak Bangsa antara WNI kepada WNA. Sedangkan dalam konteks tanah ulayat yang bersumber kepada hak bangsa, maka makna larangan pengasingannya ditujukan agar tidak ada pengasingan atau pengalihan terhadap status "ayahan" dari tanah adat dimaksud. Jadi sepanjang tanah adat tetap dalam ikatan komunal dan subjek sebagai pemegang tanah adat mau dan sanggup untuk memikul kewajiban "ayahan" dalam dimensi sosial dan religius maka pengasingan tanah adat dianggap tidak terjadi.

Konflik yang terjadi saat ini lebih dikarenakan adanya kekeliruan dalam memberi makna terhadap "larangan pengasingan" tanah adat. Oleh karena itu prajuru adat dan masyarakat adat, serta pemerintah diharapkan mampu mencermati falsafah yang mendasari penguasaan dan pemilikan tanah adat sesuai konteks kekinian dalam perspektif Hukum Agraria Nasional. 


\section{Daftar Pustaka}

\section{Buku}

Babbie, Earl. The Basics of Social Research, Amerika: Wadsworth Publishing Company, 1999.

Dijk, R. Van. Pengantar Hukum Adat Indonesia, Terjemahan: A. Soehardi, Cetakan Ketujuh, Jakarta: Sumur Bandung, 1971.

Noor, Aslan. Konsep Hak Milik Atas Tanah Bagi Bangsa Indonesia Ditinjau dari Ajaran Hak Asasi Manusia, Bandung: CV. Mandar Maju, 2006.

Harsono, Boedi. Hukum Agraria Indonesia Sejarah Pembentukan UUPA Isi dan Pelaksanaannya, Jilid I Hukum Tanah Nasional, Cetakan Kesembilan (Edisi revisi), Jakarta: Djambatan., 2003.

Siong, Gouw Giok, dan Soekahar Badwi. Tafsiran Undang-Undang Pokok Agraria, Jakarta: PT. Kinta, 1963.

Hatta, H. Mohammad. Hukum Tanah Nasional dalam Perspektif Negara Kesatuan, Cetakan I, Yogyakarta: Media Abadi, 2005.

Ibrahim, Johnny. Teori \& Metodologi Penelitian Hukum Normatif, Edisi Revisi. Cetakan Kedua, Malang: Bayumedia Publishing, 2006.

Hamidi, Jazim. Hermeneutika Hukum, Teori Penemuan Hukum Baru dengan Interpretasi Teks, Cetakan Pertama, Yogyakarta: UII Press, 2005.

Keraf, A. Sonny. Hukum Kodrat \& Teori Hak Milik Pribadi, Yogyakarta: Kanisius, 2001.

Nurjaya, I Nyoman. Pengelolaan Sumber Daya Alam dalam Perspektif Antropologi Hukum, Cetakan I, Kerjasama Progran Magister Ilmu Hukum Program Pascasarjana Unibraw, ARENA HUKUM Majalah Fakultas Hukum Universitas Brawijaya dengan Penerbit Universitas Negeri Malang (Malang: UM PRESS, 2006.

Sitorus, Oloan dan H.M. Zaki Sierrad. Hukum Agraria di Indonesia Konsep Dasar dan Implementasi, Cetakan Perdana, Yogyakarta: Mitra Kebijakan Tanah Indonesia, 2006.

- Kapita Selekta Perbandingan Hukum Tanah, Cetakan Perdana, Yogyakarta: Mitra Kebijakan Tanah Indonesia, 2004. 
Setiawan, K. Oka. Hak Ulayat Desa Adat Tenganan Pegrinsingan Bali Pasca UUPA, Cetakan I. Disertasi. Jakarta: Program Pascasarjana Fakultas Hukum Universitas Indonesia, 2003.

Simpen, IW. Kamus Bahasa Bali, Denpasar: PT. Mabhakti, 1985

Supomo, R. Hubungan Individu dan Masyarakat dalam Hukum Adat, Cetakan ke-4, Jakarta: Pradnya Paramita, 1983.

Suwitra, I Made. "Tugas Prajuru Adat Dalam Mengatur Tanah Adat Khususnya Tanah Telajakan Dalam Konsep Menuju Bali Yang Ajeg”, Jurnal Kertha Wicaksana, Fakultas Hukum Universitas Warmadewa, Denpasar, (11-1, 2005): 10-16.

Suwitra, I Made. Eksistensi Hak Penguasaan dan Pemilikan Atas Tanah Adat di Bali dalam Perspektif Hukum Agraria Nasional, Cetakan Kesatu, Bandung: Logoz Publishing, 2010.

Soemitro, Ronny Hanitijo. Metodologi Penelitian Hukum. Cetakan Pertama, Jakarta: Ghalia Indonesia, 1983.

\section{Jurnal}

Soesang Obeng, Herman. "Pertumbuhan Hak Milik Individuil Menurut Hukum Adat Dan Menurut UUPA di Jawa Timur", Majalah Hukum II (3), 1975: 49-76.

\section{Makalah}

. Pendaftaran Tanah Ulayat di Sumatra Barat dengan contoh Pilot Proyek Pendaftaran Tanah di Desa Tiga Jongkok Kecamatan Lintau Buo Kabupaten Tanah Datar, dalam Himpunan Makalah dan Rumusan Workshop Tanah Ulayat di Sumatra Barat. H. Sofyan Jalaluddin. Ed. Kantor Wilayah Badan Pertanahan Provinsi Sumatera Barat, 2000.

\section{Koran}

"Usut Tuntas Kasus Perusakan Bak Penampungan Air di Kutuh", Bali Post, 15 Januari 2010, hal. 4. 
“Tiga Opsi Selesaikan kasus Semana-Ambengan”, Bali Post, 2 Mei 2009, hal. 4.

“"klian Bajar Bucu Tolak Tanda Tangani Kesepakatan”, Bali Post, 10 Oktober 2008. hal. 4.

"Kisruh Laba Pura, Tegang "Paruman" Desa Dijaga Aparat Keamanan", Bali Post, 28 Sepetember 2009.

"Kasus tanah Adat Lemukih, Giliran Pemegang Sertifikat Datangi KP Buleleng”, Bali Post, 16 Januari 2007, hal. 5, dan 15 Agustus 2009.

"Ratusan Warga Desa Adat Kemenuh Sukawati Gianyar Turun Ke Jalan Untuk Menghadang Proses Eksekusi Tanah Sengketa Yang Oleh Warga Disinyalir Berstatus Tanah Ayahan Desa", Bali Post, 1 Maret 2006.

"Tokoh Siladan-Sema Bertemu”, Bali Post, 24 Februari 2006.

"Investor Diminta Respons Aspirasi Warga", Bali Post, 19 April 2006.

\section{Peraturan Perundang-undangan/Peraturan Desa}

Awig-Awig Desa Adat Ngis Kecamatan Manggis Kabupaten Karangasem, 1988.

Awig-Awig Desa Adat Gelgel Kecamatan dan Kabupaten Klungkung, 1980.

Awig-Awig Desa Adat Banjar Kemenuh Desa Kemenuh Kecamatan Sukawati Kabupaten Gianyar.

Awig-Awig Desa Pakraman Siladan Kecamatan dan Kabupaten Bangli.

Ketetapan MPR RI Nomor IX/MPR/2001 tentang Pembaharuan Agraria dan Pengelolaan Sumber Daya Alam.

Undang-Undang Dasar 1945 Perubahan pertama, kedua, ketiga, dan keempat.

Undang-Undang Nomor 5 Tahun 1960 tentang Peraturan Dasar Pokok-Pokok Agraria.

Peraturan Menteri Negara Agraria/Kepala Badan Pertanahan Nasional No.1/1999 tentang Tata Cara Penanganan Sengketa Pertanahạn. 
Peraturan Daerah Propinsi Daerah Tingkat I Bali Nomor 06 Tahun 1986 tentang Kedudukan, Fungsi dan Peranan Desa Adat sebagai Kesatuan Masyarakat Hukum Adat dalam Propinsi Daerah Tingkat I Bali

Peraturan Daerah Propinsi Bali Nomor 3 Tahun 2001 Jo Nomor 3 Tahun 2003 tentang Desa Pakraman. 